\title{
Erratum to: Organ donation after cardiac death: donor and recipient outcomes after the first three years of the Ontario experience
}

\author{
Roberto Hernadez-Alejandro, MD • William Wall, MD • Anthony Jevnikar, MD • \\ Patrick Luke, MD • Michael Sharpe, MD • David Russell, MD • \\ Azeem Gangji, MD • Edward Cole, MD • Sang Joseph Kim, MD, PhD • \\ Marcus Selzner, MD • Shaf Keshavjee, MD • Dianne Hebert, MD • \\ G. V. Ramesh Prasad, MD • Andrew Baker, MD • Greg Knoll, MD • \\ Robyn Winterbottom, BSc • Guiseppe Pagliarello, MD • Clare Payne, BSc • \\ Jeff Zaltzman, MD
}

Published online: 18 May 2012

(C) Canadian Anesthesiologists' Society 2012

\section{Erratum to: Can J Anesth/J Can Anesth (2011) 58:599-605 \\ DOI 10.1007/s12630-011-9511-9}

In the manuscript entitled: "Organ donation after cardiac death: donor and recipient outcomes after the first three years of the Ontario experience" published in the July 2011 issue, Can J Anesth 2011; 58: 599-605, under the names G. Knoll, R. Winterbottom and G. Pagliarello, the name of the country for Ottawa, ON, USA should read Ottawa, ON, Canada. The publisher apologizes for this error.

The online version of the original article can be found under doi:10.1007/s12630-011-9511-9.

R. Hernadez-Alejandro, MD · W. Wall, MD · A. Jevnikar, MD . P. Luke, MD

Multi-Organ Transplant Program, London Health Science

Centre, London, ON, Canada

\section{Sharpe, MD}

Department of Critical Care, London Health Science Centre, London, ON, Canada

D. Russell, MD · A. Gangji, MD

Division of Nephrology, Department of Medicine,

St. Joseph's Hospital, Hamilton, ON, Canada

E. Cole, MD · S. J. Kim, MD, PhD · M. Selzner, MD .

S. Keshavjee, MD

Multi-Organ Transplant Program, University Health Network,

Toronto, ON, Canada

D. Hebert, MD

Kidney Transplant Program, Hospital for Sick Children,

Toronto, ON, Canada

G. V. R. Prasad, MD

Division of Nephrology, Li Ka Shing Knowledge Institute,

St. Michael's Hospital, Toronto, ON, Canada

\author{
A. Baker, MD \\ Department of Anesthesia, Li Ka Shing Knowledge Institute, \\ Cara Phelan Centre for Trauma Research, St. Michael's \\ Hospital, Toronto, ON, Canada \\ G. Knoll, MD \\ Division of Nephrology, Department of Medicine, \\ The Ottawa Hospital, Ottawa, ON, Canada \\ R. Winterbottom, BSc \\ University of Ottawa Medical School, Ottawa, ON, Canada \\ G. Pagliarello, MD \\ Department of Critical Care, The Ottawa Hospital, Ottawa, ON, \\ Canada \\ C. Payne, BSc · J. Zaltzman, MD \\ Trillium Gift of Life Network, Toronto, ON, Canada \\ J. Zaltzman, MD (ه) \\ Division of Nephrology, Department of Medicine, Li Ka Shing \\ Knowledge Institute, St. Michael's Hospital, University \\ of Toronto, 61 Queen St. East, Room 9-118, Toronto, \\ ON M5C 2T2, Canada \\ e-mail: jeffrey.zaltzman@utoronto.ca
}

